\title{
Mouse models with modified p53 sequences to study cancer and ageing
}

\author{
AR Clarke ${ }^{\star, 1}$ and M Hollstein ${ }^{2}$ \\ ${ }^{1}$ Cardiff School of Biosciences, Cardiff University, Cardiff, UK \\ 2 German Cancer Research Center, Heidelberg, Germany \\ * Corresponding author: AR Clarke, Cardiff School of Biosciences, Cardiff \\ University, PO Box 911, Cardiff F10 3US, UK. E-mail: clarkeAR@ cardiff.ac.uk
}

Received 18.6.02; revised 27.9.02; accepted 16.10.02

Edited by V De Laurenzi

\begin{abstract}
Experiments with p53 transgenic and p53 gene-targeted mouse strains have substantiated, and in some cases challenged, a number of hypotheses on the biology of the p53 protein. New questions have emerged regarding similarities and differences between murine and human genetic networks in various tissues. Mouse models with targeted p53 alleles are now applied not only to investigate tumour susceptibility, but also to address questions pertinent to molecular epidemiology, chemoprevention, development of anticancer p53-specific pharmaceuticals, and ageing.

Cell Death and Differentiation (2003) 10, 443-450. doi:10.1038/ sj.cdd. 4401188
\end{abstract}

Keywords: transgenic; p53; Cre-Lox; ageing; neoplasia; murine

Abbreviations: DMBA, dimethyl-benzanthracene; TPA, 12-Otetradecanoylphorbol-13-acetate; Apc, adenomatous polyposis coli; DBD, DNA binding domain; Hupki, human p53 knock-in

\section{Introduction}

In contrast to several other genes known to be of central importance in human cancers, for example, the ras oncogenes, or the BRCA1 and 2 tumour suppressor genes, mutant p53 alleles resulting in the absence or dysfunction of p53 protein arise both in somatic cells during sporadic human tumorigenesis and in the germline (Li-Fraumeni cancer syndrome). Modelling of these two human conditions experimentally involves two distinct aims: one in which expression of mutations is delayed and confined to certain tissues to parallel sporadic cancer, and one in which the mutation is expressed in the germline. Different approaches (transgenic, knockout, knockin, conditional gene-targeting) have been used or are being considered, providing an illuminating exercise in stepwise improvements in mouse models of human cancer. The conditional gene-targeting field is still comparatively young, and conditional missense p53 mutant mouse strains are not available yet. Mice with conditionally targeted missense p53 mutations would model, for example, the typical mutation events induced by tobacco exposure in the development of human bronchial carcinomas of smokers. ${ }^{1}$ It is of particular interest to generate variants that express protein from the targeted allele (rather than to introduce deletion or stop mutants that produce no protein) because, unlike tumour mutations in other tumour suppressor genes, most human tumour p53 mutations are missense mutations in the DNA binding domain (DBD) rather than stop mutations, ${ }^{2,3}$ resulting in the accumulation of a defective protein rather than absence of p53. Furthermore, many overexpressed mutants acquire new functions that are deleterious to genome and tissue homeostasis, thus are not biologically equivalent to p53 null mutations. ${ }^{4,5}$

In the meantime, mutant p53 transgenes have permitted a first examination of the biological effects of aberrant p53 protein in mice and the phenotypic differences between null and missense mutants.

\section{P53 transgenic mice encoding mutant p53 protein (Table 1)}

Injection of DNA fragments encompassing mutant p53 gene sequences into mouse oocytes to produce a transgenic strain in which the randomly inserted exogenous sequences are stably transmitted through the germline has been relatively straightforward, permitting an initial look at the effects of mutant p53 protein on tumour susceptibility. Alan Bernstein and co-workers ${ }^{6}$ were the first to show that mice with a V135A transgene were tumour prone: spontaneously arising adenocarcinomas of the lung, osteosarcomas and lymphomas appeared on average at 11 months of age. In these strains, the transgene is present in multiple copies and overexpresses mutant murine p53 protein. The model has the appealing feature that transgene expression remains under control of endogenous murine p53 promoter sequences originally present in the injected DNA fragment. By breeding these mice with p53 gene-targeted heterozygous and homozygous mice that express no p53 protein from the mutant alleles (p53 null alleles), investigators later showed that the expressed transgene has a dominant-negative character, and predisposes to lung cancer only if the wild-type allele is also present. Susceptibility to lymphomas and sarcomas, the most common tumours in p53 null mice, remains high in mice deficient in endogenous p53, whether or not the mutant transgene is present. ${ }^{7}$ Present conjecture from a variety of experimental observations is that different p53 mutations will have different effects on overall tumour susceptibility and on spectrum, and will thus fall into different phenotypic classes that may or may not in a consistent fashion correspond to a given biochemical/ physiochemical class of p53 mutant protein (reviewed 
Table 1 Mice with Transgenic p53 Sequences

\begin{tabular}{|c|c|c|c|c|c|c|c|c|c|}
\hline Designation & Promoter & $\begin{array}{l}\text { Transgene } \\
\text { tissue } \\
\text { expression }\end{array}$ & $\begin{array}{l}\text { Coding } \\
\text { sequence } \\
\text { (cds) }\end{array}$ & $\begin{array}{l}\text { Species } \\
\text { of cds }\end{array}$ & $\begin{array}{l}\text { cds } \\
\text { mutation }\end{array}$ & $\begin{array}{l}\text { Tumour- } \\
\text { prone } \\
\text { phenotype? }\end{array}$ & $\begin{array}{l}\text { Tumour } \\
\text { type }\end{array}$ & Notes & Reference \\
\hline pL53 & Mouse p53 & Ubiquitous & $\begin{array}{l}\text { p53 gene (all exons) } \\
\text { (genome-derived, } \\
>10 \mathrm{~kb} \text { ) }\end{array}$ & Mouse & $\begin{array}{l}\text { Codon } \\
\text { A135V }\end{array}$ & $Y_{e s}^{a}$ & LADC, O, L & $\begin{array}{l}\text { p53 transgene } \\
\text { in tandem } \\
\text { copies }\end{array}$ & $\begin{array}{l}\text { Laviguer } \\
\text { et al. }{ }^{6}\end{array}$ \\
\hline [TrP53/172L] & WAP & $\begin{array}{l}\text { Mammary } \\
\text { gland }\end{array}$ & $\begin{array}{l}\text { p53 gene, exon 2- } \\
\text { exon } 11 \\
\text { (genome-derived) }\end{array}$ & Mouse & $\begin{array}{l}\text { Codon } \\
\text { R172L }\end{array}$ & $\mathrm{No}^{\mathrm{a}}$ & & hum 175 & Li et al. ${ }^{9}$ \\
\hline [TrP53/172 H] & WAP & $\begin{array}{l}\text { Mammary } \\
\text { gland }\end{array}$ & $\begin{array}{l}\text { p53 gene, exon2- } \\
\text { exon11 } \\
\text { (genome-derived) }\end{array}$ & Mouse & $\begin{array}{l}\text { Codon } \\
\mathrm{R} 172 \mathrm{H}\end{array}$ & Yes $^{b}$ & M & hum 175 & Li et al. ${ }^{10}$ \\
\hline HK1.p53m & Keratin 1 & Epidermis & p53 cds & Mouse & $\begin{array}{l}\text { Codon } \\
\mathrm{R} 172 \mathrm{H}\end{array}$ & Yes $^{b}$ & Sp, Sca & hum 175 & $\begin{array}{l}\text { Wang } \\
\text { et al. }{ }^{12}\end{array}$ \\
\hline AT3-p53 & $\begin{array}{l}\text { Anti- } \\
\text { thrombin III } \\
\text { (human) }\end{array}$ & $\begin{array}{l}\text { Liver: p53 wt } \\
\text { overexpres- } \\
\text { sion }\end{array}$ & $\begin{array}{l}5^{\prime} \text { cds and genomic } \\
\text { p53 } \\
\text { intron 2-intron11 }\end{array}$ & Mouse & Wild type & $\mathrm{No}^{\mathrm{a}}$ & & & $\begin{array}{l}\text { Gillet } \\
\text { et al. }{ }^{78}\end{array}$ \\
\hline
\end{tabular}

Abbreviations: WAP=whey acid protein; wt=wild type; LADC=lung adenocarcinoma; $\mathrm{O}=0$ steosarcoma; $\mathrm{L}=$ lymphoma; $\mathrm{M}=\mathrm{mammary}$ tumour; $\mathrm{Sp}$; Sca=skin papilloma, carcinoma ${ }^{a}$ Spontaneous tumours ${ }^{b}$ Chemically induced tumours.

recently by Bullock and Fersht). ${ }^{8}$ The human mutant analagous to murine $\mathrm{A} 135 \mathrm{~V}(\mathrm{~V} 138 \mathrm{~A})$ is not found often in human cancers ${ }^{3}$, in contrast to a more recently generated p53 missense mutation transgenic that harbours a base substitution at codon 172, equivalent (by sequence alignment) to human codon 175, which is the most common site of base substitutions in sporadic human cancers. In this strain, the mutant p53 transgene was put under control of whey acid protein regulatory sequences, allowing for high expression in mammary tissue. Two codon 172 mutant strains were generated, one replacing the $172^{\mathrm{Arg}}$ residue with leucine, and one in which histidine is substituted. ${ }^{9,10}$ In human cancers, mutants with $\mathrm{R} 175 \mathrm{H}$ are exceptionally common, whereas $\mathrm{R} 175 \mathrm{~L}$ is rare. While neither strain was susceptible to spontaneous tumours, the mutant strain with the common mutation decreased latency and increased multiplicity of tumours induced by $\mathrm{DMBA}^{10}$ and other carcinogenic agents. ${ }^{11}$ Comparable findings were reported with a transgenic model harbouring the same p53 mutation $(\mathrm{R} 172 \mathrm{H})$, but in which expression is under control of the keratin 1 promoter, directing high expression to the epidermis. Again, the mice do not reveal a tumour-prone phenotype until challenged with carcinogen. Transgenic mice treated topically with DMBA and TPA had a greater burden of skin papillomas, and of highly malignant carcinomas in particular than nontransgenic mice. $^{12}$

As with transgenics modelling of other diseases, however, the p53 strains shown in Table 1 are, at best, approximate as genetic parallels. The exogenous DNA fragment integrates as a multiple copy concatemer, the integration site is not controlled and can affect phenotype, and in most p53 transgenics the coding sequence is under the control of a strong heterologous promoter, overriding endogenous cellular controls of gene transcript levels. Use of a heterologous, tissue-specific promoter to achieve temporally or spatially restricted expression of transgenic constructs is nevertheless a rapid and accessible technique, and has provided the first tools to examine the tumourigenic role of mutant p53 in specific tissues.

A major quandary in evaluating the tumour suppressor role of p53 in mouse models stems from rapid progression and lethality of the tumour type with the shortest latency, which can preclude assessment of susceptibility to other malignancies, a difficulty that strains with tissue-restricted expression of modified p53 can circumvent. A second problem, one that plagues comparisons of tumour susceptibility among the p53modified strains by whatever means they are generated, is the influence of genetic background on tumorigenesis. ${ }^{13}$

\section{P53 mice generated by gene-targeting technology (Table 2)}

\section{Knockout mice}

Constitutive inactivation of p53 through gene targeting has allowed the in vivo analysis of loss of p53 activity, and has circumvented some of the difficulties associated with conventional transgenic approaches. P53 null mice have been generated by several different groups, and, despite subtle differences in the targeting strategies adopted, all strains exhibit very similar phenotypes. ${ }^{14-16}$ Perhaps, the first major surprise from these analyses was that p53 was largely dispensable for normal embryonic development, with all the deficient strains being initially reported as viable. A closer look, however, has made it clear that p53 does play a role in normal embryonic development. Both Armstrong et al. ${ }^{17}$ and Sah et al. ${ }^{18}$ have reported significant in vivo female lethality, which is heavily influenced by background such that on a 129 background almost all female embryos develop neural tube defects and die in utero. The precise reason underlying this 
Table 2 Mouse Strains With Modified p53 Alleles

\begin{tabular}{|c|c|c|c|c|c|c|c|}
\hline & $\begin{array}{l}\text { Publication } \\
\text { year }\end{array}$ & $\begin{array}{l}\text { allele } \\
\text { designation }^{a}\end{array}$ & $\mathrm{Ct}, \mathrm{Cn}, \mathrm{Ch}$ & $\begin{array}{l}\text { Novel } \\
\text { sequence: }\end{array}$ & Effects & $\begin{array}{l}\text { Tumour } \\
\text { prone }\end{array}$ & $\begin{array}{l}\text { Primary } \\
\text { reference }\end{array}$ \\
\hline \multirow[t]{5}{*}{$\begin{array}{l}\text { (A) Knockout } \\
\text { strains }\end{array}$} & 1992 & $\begin{array}{l}\text { p53 null } \\
\text { (p53-) }\end{array}$ & $\mathrm{Ct}$ & $\begin{array}{l}\text { (Neomycin); deletion } \\
\text { in p53 exon } 5\end{array}$ & No p53 protein & Yes $(L, S)$ & Donehower et al. ${ }^{15}$ \\
\hline & 1993 & p53 null & $\mathrm{Ct}$ & $\begin{array}{l}\text { (Neomycin); deletion } \\
\text { of p53 exons } 2-6\end{array}$ & No p53 protein & Yes (L) & Clarke et al. ${ }^{14}$ \\
\hline & 1994 & $\begin{array}{l}\text { p53 null } \\
\text { (p53-) }\end{array}$ & $\mathrm{Ct}$ & $\begin{array}{l}\text { (Neomycin); deletion } \\
\text { of p53 exons } 2-6\end{array}$ & No p53 protein & Yes & Jacks et al. ${ }^{24}$ \\
\hline & 2001 & Trp53F2-10 & $\mathrm{Cn}$ & $\begin{array}{l}\text { Deletion of p53 exons } \\
2-10 \text { in epithelial cells }\end{array}$ & No p53 protein & (Yes) & Jonkers et al. ${ }^{60}$ \\
\hline & 2002 & $\mathrm{p} 53+/ \mathrm{m}$ & $\mathrm{Ct}$ & $\begin{array}{l}\text { Deletion of } p 53 \text { exons } \\
1-6 \text {, and mutation } \\
\text { at } c .245\end{array}$ & $\begin{array}{l}\text { Nontargeted p53 } \\
\text { is overexpressed }\end{array}$ & $\begin{array}{l}\text { Tumour resistant; } \\
\text { accelerated ageing }\end{array}$ & $\begin{array}{l}\text { Marino et al. }{ }^{59} \\
\text { Tyner et al. }{ }^{61}\end{array}$ \\
\hline \multirow[t]{4}{*}{$\begin{array}{l}\text { (B) Knockin } \\
\text { strains }\end{array}$} & 2000 & Trp53QS & $\mathrm{Ct}$ & Mutation at c.25,26 & $\begin{array}{l}\text { Loss of trans-activation } \\
\text { by p53 }\end{array}$ & (Yes) & Jimenez et al. ${ }^{65}$ \\
\hline & 2000 & p53R172H & $\mathrm{Ct}$ & $\begin{array}{l}\text { in TA domain } \\
\text { Mutation at c. } 172 \text {, and } \\
\text { at intron splice site }\end{array}$ & $\begin{array}{l}\text { Low mutant protein } \\
\text { expression }\end{array}$ & Yes $(L, C)$ & Liu et al. ${ }^{64}$ \\
\hline & 2001 & Hupki (p53KI) & $\mathrm{Ct}$ & $\begin{array}{l}\text { Human wild-type sequences } \\
\text { from introns } 3 \text { to } 9\end{array}$ & $\begin{array}{l}\text { Functional chimeric } \\
\text { hum/mus p53 }\end{array}$ & (No) & Luo et al. ${ }^{67}$ \\
\hline & 2001 & $\begin{array}{l}\text { p53+/R270H } \\
\text { p53+/P275S }\end{array}$ & $\mathrm{Ch}$ & $\begin{array}{l}\text { Missense mutation } \\
\text { at c. } 270 \\
\text { Missense mutation } \\
\text { at c. } 275\end{array}$ & Reduced apoptosis & $N G$ & De Vries et al. ${ }^{66}$ \\
\hline
\end{tabular}

Abbreviations: Ct: constitutional; Cn: conditional; Ch: chimeric mice (germline transmission not reported) c., codon; cds, coding sequence; hum, human; mus, mouse; $\mathrm{TA}$, transactivation domain; NG, not given; ${ }^{\mathrm{a}}$ As given by authors

phenotype remains somewhat unclear, although a role for p53 in suppressing radiation-induced teratogenesis has been demonstrated suggesting that p53 may play a role as 'guardian' of the embryo through the deletion of aberrant cells. ${ }^{19,20}$ An even clearer demonstration of the relevance of p53 to normal development comes from analyses of mice bearing inactivating mutations of the p53 regulators Mdm2 and Mdm4. These proteins both regulate p53 activity, either by targeting p53 for degradation or by specifically inhibiting p53 transcriptional activity. Deficiency of both of these genes results in early embryonic lethality, nonoverlapping phenotypes both rescued by the absence of $p 53 .^{21,22}$ This role for p53 is further underlined by the partial rescue of the lethal phenotype associated with Brca1 mutation, normally characterized by decreased cellular proliferation and reduced levels of Mdm2. ${ }^{23}$

It rapidly became evident that p53-deficient mice were strongly predisposed to neoplasia, with spontaneous development of tumours being widely reported, ${ }^{15,24,25}$ although the spectrum of lesions differed from that predicted by the LiFraumeni syndrome with a notable absence of tumours of epithelial origin. As might have been predicted, challenge of these mice by radiation or carcinogen (e.g. dimethylnitrosamine) accelerated neoplasia development. ${ }^{26,27}$ However, apparently paradoxical results were obtained from some systems, highlighting an emerging complex reliance upon p53 in tumour suppression. For example, in a well-characterised model of skin tumorigenesis, p53 deficiency was shown to protect against formation of the initial lesion (papilloma), although greatly accelerated progression to malignancy. ${ }^{28}$ Similar results were obtained from other models of skin tumorigenesis, reliant upon the keratin $\mathrm{K} 1$ promoter to drive expression of either v-rasHa, v-fos or TGF alpha to the epidermis. Here again p53 deficiency failed to simply predispose to neoplasia. ${ }^{29}$ These studies suggest that, in certain systems, p53 deficiency may actually cause the deletion of cells bearing excessive DNA damage by failing to permit normal attempts at repair.

While some studies have yielded apparently paradoxical results, the majority of intercrosses have underpinned our understanding of p53 as a potent tumour suppressor. For example, in direct contrast to the epithelial model, overexpression of TGF alpha in the pancreas leads to ductal tumorigenesis, which is dramatically accelerated by the absence of $p 53 .{ }^{30}$ Similar synergy in pancreatic acinar cell neoplasia has been demonstrated between p53 deficiency and the Min mutation of the Apc (adenomatous polyposis coli) gene. ${ }^{31}$ Indeed, p53-deficient mice are now frequently viewed as a baseline upon which to test other potential tumour predisposing events, with the result that the list of genetic changes for which in vivo synergy can be shown with p53 is extensive, ranging from overexpression to misexpression to gene deficiency. For example, excess E2F1 has been shown to lead to increased skin carcinoma in the absence of $p 53 ;^{32}$ misexpression of casein kinase II leads to accelerated lymphoma development; ${ }^{33}$ and combined inactivation of genes (such as the decorin gene) can reveal tumour predisposition otherwise undetectable. ${ }^{34}$ In very occasional 
instances this type of analysis has failed to clearly determine interactions with p53. For example, apparently contradictory results have been generated for PARP-1 deficiency, whereby inactivation of PARP-1 has been shown to both increase ${ }^{35}$ or decease tumour latency ${ }^{36}$ in the absence of p53. Such diametrically opposed results must reflect stark differences in the gene dependency within specific cell systems, and strongly warn against drawing broad, global conclusions concerning the consequences of p53 loss.

PARP-1 plays a role in the immediate response to DNA damage, and analysis such as those described above naturally arose from the pursuit of mechanisms by which p53 mediates tumour suppression. The use of p53 null alleles has proven particularly potent here, with roles now demonstrated in mediating damage signals, modulating transcription, genomic stability, cell cycle arrest, and the induction of cell death. A series of intercrosses have also begun to address where p53 lies within the damage response hierarchy. For example, deficiency of the recombinational repair protein rad51 results in embryonic lethality, which can at least be partially rescued by p53 deficiency. ${ }^{37}$ Similarly, neoplasia is dramatically accelerated in mice deficient in both p53 and the damage sensor protein atm, indicating clear synergy in tumour suppression here, although also a degree of redundancy to other responses such as the apoptotic response to ionising radiation. ${ }^{38}$ One point that should be noted here is the possibility that p53 deficiency may be able to 'rescue' some of the DNA damage mutants that would normally invoke p53-dependent death, so raising a note of caution about the interpretation of these crosses.

The null mice have given significant insights into the mechanics of tumour suppression, for example, acceleration genomic instability in many systems such as mammary tumorigenesis driven by Wnt-1 transgene expression. ${ }^{39}$ One of the most significant discoveries has been the requirement for functional p53 to mediate apoptosis following DNA damage. ${ }^{14,16,40}$ This gave rise to the notion of p53 as 'guardian' as it would normally function to delete cells (through apoptosis) bearing excess DNA damage. This hypothesis yields several predictions for a p53 null environment: there should be increased clonogenic survival following DNA damage, and surviving clones would be characterised by higher levels of mutation and a greater predisposition to neoplasia. This hypothesis also predicts that p53 status will be a critical determinant of clinical outcome, where apoptosis is an important mediator of chemosensitivity.

Many of these outcomes have been tested directly using the null mice, with extremely varied results. Thus, although p53 may be shown to confer increased clonogenic survival in many in vitro assays, ${ }^{41}$ this has been difficult to establish in vivo with ionising radiation. Thus, despite clear loss of the apoptotic programme, p53 deficiency has relatively little effect upon clonogenic survival in the small intestine as measured by the microcolony assay. ${ }^{42,43}$ Part of the reason for this appears to be that survival of the crypt following ionising radiation is primarily defined by survival of the endothelial cells, rather than of the enterocytes. ${ }^{44}$ This explanation fits well with more recent observations using agents other than ionising radiation (cisplatin), where increased clonogenic survival can be observed in this system in the absence of p53. ${ }^{45}$

Even more surprisingly, it has been extremely difficult to show that p53 deficiency confers an increased mutation burden. Studies scoring spontaneous mutation in either a lacZ transgene or at the endogenous $D l b-1$ locus failed to show increased mutation frequencies in a range of tissues. ${ }^{46,47}$ Even following exposure to the powerful mutagen ENU, p53 status made little impact upon mutation frequency. ${ }^{48}$ It is however clear that within certain systems, p53 deficiency will confer increased mutation burden, as has been reported in pre-B cells. ${ }^{41}$ Significantly, the authors of this study also showed that this increase probably derived from increased clonogenic survival.

Despite these differences, it is clear that the p53 status can be a determinant of outcome after anticancer therapy in vivo ${ }^{63}$; and further, that the ability to engage apoptosis can be an important determinant of neoplasia (reviewed in Johnstone et al. $^{49}$ ). This has been shown many times; for example, by the direct demonstration that p53 can induce apoptosis and suppress tumorigenesis in an SV40 T antigen fragment model; ${ }^{50}$ or by the observation that p53 deficiency abrogates apoptosis mediated by hypoxia, so promoting survival within tumour masses. ${ }^{51}$ Perhaps some of the best examples derive from studies of p53-dependent, c-Mycinduced apoptosis. ${ }^{52}$ The importance of c-Myc-driven death to neoplasia was recently elegantly underlined by Pelengaris et al., ${ }^{53}$ who used an inducible c-myc transgene to show that tumorigenesis driven by c-myc is absolutely dependent upon loss or suppression of the apoptotic programme.

In essence, these studies have demonstrated that p53 status and the ability to engage apoptosis can be critical to both carcinogenesis and neoplastic progression. However, the relations are not simplistic and often system dependent. This makes generalisations very difficult or impossible to draw. Nowhere is this more evident than in the ongoing debate as to whether p53 status can be used as a good prognostic indicator of clinical outcome.

Although homozygous p53 null animals have yielded a mass of information, mice characterised by germline p53 absence (p53-/-) remain relatively limited as genetic models of human disease, particularly since a second somatic mutation of p53 usually occurs during tumorigenesis. Heterozygous (p53 +/-) mice should therefore be a more appropriate model, and it is therefore encouraging that high incidence of mammary neoplasia has now been reported in p53 heterozygotes when on a BALB/c background. ${ }^{54}$ One question that has persisted throughout these analyses is that of p53 gene dose dependency. Although it has been shown repeatedly that when one allele is mutated, the second hit at the remaining wild type usually follows, and reveals latent phenotype. It is becoming increasingly clear, however, that reduction to one functional p53 allele already confers a phenotype. Thus, cellular responses to DNA damage such as gene induction can be shown to be p53 dose-dependent. ${ }^{55}$ Perhaps, the clearest indication of a heterozygous phenotype stems from the observation that a proportion of tumours arising in p53 (p53 +/-) heterozygotes retain p53 functionality. ${ }^{56}$ More recently, we have shown that heterozygosity for p53 can accelerate microsatellite instability in a mismatch 
repair-deficient context. ${ }^{57}$ It seems likely that the consequences of such dose-dependent effects are currently being overlooked simply because reduction in p53 activity is difficult to score and therefore usually not addressed in the majority of studies, whether in humans or in the mouse.

There are two further potentially serious caveats to the p53 null mice. First, their very high predisposition to lymphoma effectively limits their lifespan and precludes studies of tumorigenesis characterised by long latencies. Second, because the null mice develop entirely in the absence of p53 there is a strong possibility that developmental compensation has occurred such that absence of p53 in the null mouse poorly models somatic loss of p53. One approach to the first of these problems has been to generate multiply mutant strains, as discussed briefly above. A second approach has been to use transplanted material, for example, by repopulating cleared mammary fat pads of wild-type mice with p53 null mammary epithelium. ${ }^{58}$ Even this strategy, however, cannot deal with the issue of developmental compensation. A more satisfying genetic approach to both issues has been the creation of conditional p53 alleles through use of the Cre-LoxP system. Essentially, this system permits tissue-specific inactivation of any gene of choice by Crerecombinase-mediated recombination between two $34 \mathrm{bp}$ loci or LoxP sequences. Insertion of the LoxP sites, usually into intronic sequences, is predicted not to perturb expression. However, following exposure to Cre recombinase, the region flanked by the LoxP sites is deleted. This strategy is usually designed to mediate gene inactivation. In the case of p53, LoxP sites were placed in introns 1 and 10, and Cre expression delivered by conventional transgenesis to either the granular layer cells of the cerebellum using the GFAP promoter, ${ }^{59}$ or to the mammary epithelium using the keratin 14 promoter. ${ }^{60}$ Both of these experiments resulted in tissuespecific inactivation of $\mathrm{p} 53$, which accelerated neoplasia in each tissue in conjunction with Cre-mediated loss of either retinoblastoma or Brca2. These examples have established the potential of this approach for analysing p53 function in any tissue, dependent upon Cre delivery. It is notable that, as yet, this strategy has not been used to address the issue of developmental compensation.

One somewhat unconventional p53 mutant was reported earlier this year. ${ }^{61}$ This strain was generated as a consequence of an aberrant targeting event originally designed to introduce a mutation at codon 245 (Arg245Trp). Although the codon 245 mutation was introduced, exons 1-6 of p53 were deleted, together with an undefined upstream region extending at least $20 \mathrm{~kb}$. Somewhat surprisingly, this mutant allele, which can produce a truncated C-terminal p53 protein fragment in vitro, confers a novel phenotype, possibly by augmenting stabilisation of wild-type p53. Mice carrying one copy of this mutant allele $\left({\left.\mathrm{p} 53^{+/ m}\right)}\right.$ show multiple signs of premature ageing and have a greatly reduced lifespan (the phenotype of the homozygous mutants has not yet been reported). The authors also argue that the mutant allele suppresses neoplasia as fibroblasts derived from the $\mathrm{p} 53^{+/ \mathrm{m}}$ mice show resistance to transformation and substantially reduced tumour incidence at the time of death when compared to their $\mathrm{p} 53^{+/+}$and $\mathrm{p} 53^{+/-}$counterparts. Although this latter phenomenon may simply reflect greatly truncated lifespan, the observation of p53-associated early senescence is clearly of importance, with data from murine embryonic fibroblasts also supporting the idea that the ability to induce senescence is partly dependent upon $p 53 .{ }^{62}$ The notion that cellular senescence truly occurs in vivo is still somewhat controversial, as indeed is the potential of senescence programmes to modify the response to chemotherapy. However, Schmitt et al. ${ }^{63}$ have recently used p53 heterozygous mice to study the response to chemotherapy and show, in a series of experiments, both p53 and p16 ${ }^{\mathrm{INK} 4}$ can mediate in vivo senescence, or at the very least multiple cellular changes consistent with senescence.

\section{Knockin mice}

The p53 knockout models have been of unquestionable value in revealing the importance of p53 loss of function in tumorigenesis; however, we are still faced with the fact that the great majority of human cancers, rather than showing an absence of 553 protein and function, overexpresses mutant p53 protein that has lost wild-type function and has gained new tumour-promoting properties. The human tumour missense mutations map, with rare exception, to the DBD of the gene. DBD mutant strains would provide a tool to explore the particular biological properties of the different mutant p53 proteins found in sporadic tumours. Knockin strains with p53 DBD missense mutations also would represent appropriately the inherited Li-Fraumeni p53 variants, because the mutations most frequently detected in sporadic cancers are also the most common mutations in Li-Fruameni families. Up to the present, efforts to generate mice with germline expression of a missense mutation equivalent to a common Li-Fraumeni inherited mutation either have been unsuccessful, or have produced unexpected, spontaneously modified p53 alleles during the gene-targeting procedure. ${ }^{61,64}$ Given the human experience, this is somewhat puzzling at first glance because affected individuals in Li-Fraumeni cancer syndrome families with one wild type and one mutant p53 allele transmit the mutant allele to their progeny, and germline transmission in mice of transgenes overexpressing mutant p53 has been successful also (Table 1, and the section on p53 transgenic mice encoding mutant p53 protein). Difficulties in producing an Li-Fraumeni mutant mouse model are thought to lie in the deleterious effects of an expressed gain-of function mutation on embryonic stem cells during in vitro manipulation. The only germline targeted p53 DBD mutant mouse reported thus far harbours not only a common tumour missense mutation $(\mathrm{R} 172 \mathrm{H})$, but also a fortuitous splice site mutation that severely compromises expression of the mutant allele, ${ }^{64}$ which may explain why this mouse with constitutive expression of this missense mutation could be generated. Various protocol modifications are now at hand to avoid pitfalls in generating mice with germline transmission of p53 DBD missense mutations.

Whereas modelling of DBD mutants in mice with genetargeting approaches presents special challenges, production of mutant strains with knockin missense mutations in other domains of the gene (e.g. that regulate activity of the encoded protein) has been relatively unproblematic and the mutant mice have brought clarity to a plethora of data from somewhat 
contradictory in vitro experiments. A central question in p53 tumour biology has been whether the transcriptional transactivation function of $p 53$ is essential for tumour suppression and p53-mediated apoptosis. Wahl and co-workers ${ }^{65}$ generated a mouse harbouring missense mutations in the transactivation domain of the endogenous murine p53 gene to address this issue. The mutant protein, which bears two adjacent amino-acid substitutions at residues 25 and 26 , while still able to bind to p53 response elements in DNA, is deficient in transactivation, compromises p53-dependent apoptosis in thymocytes in vivo, and renders embryonic fibroblasts tumourigenic. The homozygous mice are tumour prone. These in vivo data argue convincingly that transactivation by p53 is crucial to its tumour suppressor function, and outweigh contradictory inferences from in vitro experimental systems. Not surprisingly, evidence both from analysis of human tumour samples and from experimental work in cell lines indicates that most, if not all, DBD missense mutations are defective in apoptosis induction and are unable to activate transcription of downstream genes, because binding and contact with DNA at promoter response elements is faulty or absent. Thymocytes harvested from chimeric mice harbouring either of the two common mutations in exon 8 of p53 are also deficient in p53-dependent apoptosis. ${ }^{66}$

In mouse strains with altered p53 gene sequences described in the literature thus far the modified p53 sequences are murine-derived, with one exception. In the Hupki (for human p53 knockin) model, we replaced the murine p53 sequences encoding the polyproline and DNA-binding domains with homologous sequences from the human genome, and we designed the strain to retain rather than compromise p53 wild-type function, in contrast to other p53-targeted strains. ${ }^{67}$ Homozygous Hupki mice indeed develop normally and show wild-type p53 responses to DNA-damaging agents. ${ }^{67,68}$ Nevertheless, differences exist between the human and mouse p53 genetic network, and human p53 does not behave identically to murine p53 in mouse cells. ${ }^{69,70}$ An in-depth comparison of p53 function in Hupki mice with mice harbouring unmodified murine p53 (in particular, by molecular profiling with high density arrays to examine transcriptional responses) should contribute to an evaluation of strain and species differences in this context.

There are several fields of application for the prototype Hupki humanized p53 strain and derivatives: (i) Molecular epidemiology: a mutation spectrum, whether in the mouse or the human p53 gene, can provide important information on the nature of the exogenous and endogenous mutagenic factors that gave rise to the mutations. The p53 core domains of mice and humans differ at $15 \%$ of base residues and the mutation spectrum is dependent on exact DNA base context, so spectrum comparisons become more difficult between species. (ii) In vivo testing of drugs targeting human p53 protein for pharmacological rescue of apoptotic function: the aminoacid sequences of mouse and human p53 core domains differ at $10 \%$ of residues, and homology is lower for the polyproline and apoptosis regulatory domains. The p53 protein is affected significantly by single amino-acid substitutions, ${ }^{2}$ and single amino-acid intragenic suppressors of p53 mutants have been discovered. ${ }^{71,72}$ The Hupki strain offers an opportunity to test new compounds in an in vivo model presenting the human core domain, or core domain mutant, as target. (iii) Regulation of p53 activity: phosphorylation of Ser46 is important for the induction of p53-dependent apoptosis in human cells. ${ }^{73-76}$ Murine p53 lacks a serine at or near this location. In Hupki mice, the human sequence-derived residues of the chimeric protein include Ser46, and phosphorylation occurs in Hupki mouse cells in response to DNA damage ( $\mathrm{J}-\mathrm{L}$ Luo and $M$ Hollstein, unpublished observations).

\section{Implications and new directions}

The availability of the p53 mutant strains reviewed here has greatly accelerated our understanding of the biological roles played by $\mathrm{p} 53$. These strains, however, have also shown this biology to be exceedingly complex and often highly context dependent. Thus, although it is very clear that loss of p53 can impact upon a plethora of pathways relevant to neoplasia, the precise importance of each of these pathways remains relatively unclear. Similarly, we do not yet truly understand the biological ramifications of subtle mutation to $\mathrm{p53}$, such as altered phosphorylation. These are difficulties that we can now address either by exploiting existing strains or by the creation of new variants. Effectively, we can now mutate the p53 gene in any way we choose to; furthermore, we can upregulate or inactivate any of these mutants both temporally and spatially. Some of these mutant strains, such as the conditional p53 allele and the Hupki mouse already exist; others remain to be established.

The questions we can resolve with these strains should be manifold. Most pertinently, we will be able to determine the consequences of specific mutations in specified tissues, so building much better models of human tumorigenesis. We also should be able to address the therapeutic consequences of reactivating potentially therapeutic genes within these mutant contexts, using technology similar to that recently demonstrated for c-myc. ${ }^{53}$ Allied to such a test of genetic modification of tumour predisposition, these p53 mutants are also available for the screening of chemopreventative agents, an area that until now has been relatively little pursued. Finally, we should be aware that p53 does not function in isolation, and that now, through the use of expression profiling, ${ }^{77}$ we have an outstanding opportunity to examine the genetic networks within which p53 functions.

\section{References}

1. Hainaut $P$ and Pfeifer GP (2001) TP53 mutational spectrum in lung cancers and mutagenic signature of components of tobacco smoke: lessons from the IARC TP53 mutation database. Carcinogenesis 22: 367-374

2. Hainaut $P$ and Hollstein M (2000) P53 and human cancer: the first ten thousand mutations. Adv. Cancer Res. 77: 81-137

3. Olivier M, Eeles R, Hollstein M, Khan MA, Harris CC and Hainaut $P(2002)$ The IARC TP53 database: new online mutation analysis and recommendations to users. Hum. Mutation 19: 607-614

4. Dittmer D, Pati S, Zambetti G, Chu S, Teresky AK, Moore M, Finlay C and Levine AJ (1993) Gain of function mutations in p53. Nat. Genet. 4 42-45

5. Gualberto A, Aldape K, Kozakiewicz K and Tlsty TD (1998) An oncogenic form of p53 confers a dominant, gain-of-function phenotype that disrupts spindle checkpoint control. Proc. Natl. Acad. Sci. USA 95: 5166-5171 
6. Laviguer A, Maltby V, Mock D, Rossant J, Pawson T and Bernstein A (1989) High incidence of lung, bone, and lymphoid tumours in transgenic mice overexpressing mutant alleles of the p53 oncogene. Mol. Cell Biol. 9: 39823991

7. Harvey M, Vogel H, Morris D, Bradley A, Bernstein A and Donehower LA (1995) A mutant p53 transgene accelerates tumour development in heterozygous but not nullizygous p53-deficient mice. Nat. Gene. 9: 305-311

8. Bullock AN and Fersht AR (2001) Rescuing the function of mutant p53. Nat. Cancer Rev. 1: 68-76

9. Li B, Greenberg N, Stephens LC, Mayn R, Medina D and Rosen JM (1994) Preferential overexpression of a 172Arg->Leu mutant p53 in the mammary gland of transgenic mice results in altered lobuloalveolar development. Cell Growth Different. 5: 711-721

10. Li B, Murphy KL, Laucirica R, Kittrell F, Medina D and Rosen JM (1998) A transgenic mouse model for mammary carcinogenesis. Oncogene 16: 9971007

11. Medina D, Ullrich R, Meyn R, Wiseman R and Donehower L (2002) Environmental carcinogens and p53 tumour-suppressor gene interactions in a transgenic mouse model for mammary carcinogenesis. Environ. Mol. Mutagen. 39: $178-183$

12. Wang X-J, Greenhalgh DA, Jiang A, He D, Zhong L, Medina D, Brinkley BR, and Roop DR (1998) Expression of a p53 mutant in the epidermis of transgenic mice accelerates chemical carcinogenesis. Oncogene 17 35-45

13. Harvey M, McArthur MJ, Montgomery Jr. CA, Bradley A and Doenhower LA (1993a) Genetic background alters the spectrum of tumours that develop in p53-deficient mice. FASEB J. 7: 938-943

14. Clarke AR, Purdie CA, Harrison DJ, Morris RG, Bird CC, Hooper M L and Wyllie AH (1993) Thymocyte apoptosis induced by p53-dependent and independent pathways. Nature 362: 849-852

15. Donehower LA, Harvey M, Slagle BL, McArthur MJ, Montgomery CA, Butel JS and Bradley A (1992) Mice deficient for p53 are developmentally normal but susceptible to spontaneous tumours. Nature 356: 215-221

16. Lowe SW, Schmitt EM, Smith SW, Osborne BA and Jacks T (1993) p53 is required for radiation-induced apoptosis in mouse thymocytes. Nature 362 : $847-849$

17. Armstrong JF, Kaufman MH, Harrison DJ and Clarke AR (1995) High frequency developmental abnormalities in p53 deficient mice consistent with acquired mutations. Curr Biol 5: 931-936

18. Sah VP, Attardi LD, Mulligan GJ, Williams BO, Bronson RT and Jacks T (1995) A subset of p53-deficient embryos exhibit exencephaly. Nat. Genet. 10: 175180

19. Norimura T, Nomoto S, Katsuki M, Gondo $Y$ and Kondo S (1996) p-53dependent apoptosis suppresses radiation induced teratogenesis. Nat. Med. 2 $525-526$

20. Hall PA and Lane DP (1997) Tumour suppressors: a developing role for p53?. Curr. Biol. 7: R144-R147

21. Jones SN, Roe AE, Donehower LA and Bradley A (1995) Rescue of embryonic lethality in Mdm-2 deficient mice by absence of p53. Nature 9: 206208.

22. Hakem R, de la Pompa JL, Elia A, Potter J and Mak TW (1997) Partial rescue of Brca1 (5-6) early embryonic lethality by p53 or p21 null mutation. Nat. Gene. 16: 298-302

23. Parant J, Chavez-Reynes A, Little NA, Yan W, Reinke V, Jochemsen AG Lozano G (2001) Rescue of embryonic lethality in Mdm4-null mice by loss of p53 suggests a nonoverlapping pathway with Mdm2 to regulate p53. Nat. Gene. 29: 92-95

24. Jacks T, Remington L, Williams BO, Schmitt EM, Halachmi S, Bronson RT and Weinberg RA (1994) Tumour spectrum analysis in p53-mutant mice. Cur. Biol. 1: 4-7

25. Purdie CA, Harrison, DJ, Peter A, Dobbie L, White S, Howie SEM, Salter DM, Bird CC, Wyllie AH, Hooper ML and Clarke AR. (1994) Tumour incidence, spectrum and ploidy in mice with a large deletion in the p53 gene. Oncogene 9 : 603-609

26. Harvey M, McArthur MJ, Montgomery CA, Butel JS, Bradley A and Donehower LA (1993) Spontaneous and carcinogen induced tumorigenesis in p53 deficient mice. Nat. Gene. 5: 225-229

27. Kemp CJ, Wheldon T and Balmain A (1994) p53 deficient mice are extremely susceptible to radiation-induced tumorigenesis. Nat. Gene. 8: 66-69
28. Kemp CJ, Donehower LA, Bradley A and Balmain (1993) Reduction of p53 gene dosage does not increase initiation or promotion but enhances malignant progression of chemically induced skin tumours. Cell 74: 813822

29. Greenhalgh DA, Wang XJ, Donehower LA and Roop DR (1996) Paradoxical tumour inhibitory effect of p53 loss in transgenic mice expressing epidermal targeted v-rasHa, v-fos, or human transforming growth factor alpha. Cancer Res. 56: 4413-4423

30. Wagner M, Greten FR, Weber CK, Koschnick S, Mattfeldt T, Deppert W, Kern $H$, Adler $G$ and Schmid RM (2001) A murine tumour progression model for pancreatic cancer recapitulating the genetic alterations of the human disease. Genes Dev. 15: 286-293

31. Clarke AR, Cummings MC and Harrison DJ (1995) Interaction between murine germline mutations in p53 and APC predisposes to pancratic neoplasia but not to increased intestinal malignancy. Oncogene 11: 1913-1920

32. Pierce AM, Gimenez-Conti IB, Schneider-Broussard R, Martinez LA, Conti CJ and Johnson DG (1998) Increased E2F1 activity induces skin tumours in mice heterozygous and nullizygous for p53. Proc. Natl. Acad. Sci. USA 95: 88588863

33. Landesman-Bollag E, Channavajhala PL, Cardiff RD and Seldin DC (1998) P53 deficiency and misexpression of protein kinase CK2alpha collaborate in the development of thymic lymphomas in mice. Oncogene 16: 2965-2974

34. Iozzo RV, Chakrani F, Perotti D, McQuillan DJ, Skorski T, Calbretta B and Eichstetter I (1999) Cooperative action of germ-line mutations in decorin and p53 accelerates lymphoma tumorigenesis. Proc. Natl. Acad. Sci. USA 96: 3092-3097

35. Conde C, Mark M, Oliver FJ, Huber A, de Murcia G and Menissier de Murcia J (2001) Loss of poly(ADP-ribose) polymerase-1 causes increased tumour latency in p53-deficient mice. EMBO J 20: 3535-3543

36. Beneke R and Moroy T (2001) Inhibition of poly(ADP-ribose) polymerase activity accelerates T-cell lymphomagenesis in p53-deficient mice. Oncogene 20: $8136-8141$

37. Lim DS and Hasty P (1996) A mutation in mouse rad51 results in an early embryonic lethality that is suppressed by a mutation in p53. Mol. Cell. Biol. 16: 7133-7143

38. Westphal CH, Rowan S, Schmaltz C, Elson A, Fisher DE and Leder P (1997) atm and p53 cooperate in apoptosis and suppression of tumorigenesis, but not in resistance to acute radiation toxicity. Nat. Gene. 16: 397-401

39. Donehower LA, Godley LA, Aldaz CM, Pyle R, Shi YP, Pinkel D, Gray J, Bradley A, Medina D and Varmus HE (1995) Deficiency of p53 accelerates mammary tumorigenesis in Wnt-1 transgenic mice and promotes chromosomal instability. Genes Dev. 9: 882-895

40. Clarke AR, Gledhill S, Hoper ML, Bird CC and Wyllie AH (1994) p53 dependence of early apoptotic and proliferative responses within the mouse intestinal epithelium following gamma-irradiation. Oncogene 9: 17671773

41. Griffiths SD, Clarke AR, Healy LE, Ross G, Ford AM, Hooper ML, Wyllie AH and Greaves M (1997) Absence of p53 promotes propagation of mutant cells following genotoxic damage. Oncogene 14: 523-531

42. Hendry JH, Cai WB, Roberts SA and Potten CS (1997) P53 deficiency sensitizes clonogenic cells to irradiation in the large but not the small intestine. Radiat. Res. 148: 254-259

43. Hendry JH, Broadbent DA, Roberts SA and Potten CS (2000) Effects of deficiency in $\mathrm{p} 53$ or bcl-2 on the sensitivity of clonogenic cells in the small intestine to low dose rate irradiation. Int. J. Radiat. Biol. 76: 559-565

44. Paris F, Fuks Z, Kang A, Capodieci P, Juan G, Ehleiter D, Haimovitz-Friedman A, Cordon-Cardo C and Kolesnick R (2001) Endothelial apoptosis as the primary lesion initiating intestinal radiation damage in mice. Science 293: 293297

45. Sansom OJ and Clarke AR (2002) The ability to engage apoptosis does not predict long term enterocyte survival in p53 and Msh2 deficient mice. Oncogene 21: 5934-5939

46. Nishino H, Knoll A, Buettner VL, Frisk CS, Maruta Y, Haavik J and Sommer SS (1995) P53 wild type and p53 nullizygous big blue transgenic mice have similar frequencies and patterns of observed mutation in liver, spleen and brain. Oncogene 11: 263-270

47. Clarke AR, Howard LA, Harrison DJ and Winton DJ (1997) p53 mutation frequency and apoptosis in the murine small intestine. Oncogene 14: 20152018 
48. Giese H, Snyder WK, van Oostrom C, van Steeg H, Dolle ME and Vijg J (2002) Age related mutation accumulation at the lacZ reporter locus in normal and tumour tissues of Trp53-deficient mice. Mutat. Res. 514: 153-163

49. Johnstone RW, Ruefli AA and Lowe SW (2002) Apoptosis: a link between cancer genetics and chemotherapy. Cell 108: 153-164

50. Symonds H, Krall L, Remington L, Saenz-Robles M, Lowe S, Jacks T and Van Dyke T (1994) p53-dependent apoptosis suppresses tumour growth and progression in vivo. Cell 78: 703-711

51. Graeber TG, Osmanian C, Jacks T, Housman DE, Koch CJ, Lowe SW and Giaccia AJ (1996) Hypoxia-mediated selection of cells with diminished apoptotic potential in solid tumours. Nature 379: 88-91

52. Hermeking $\mathrm{H}$ and Eick D (1994) Mediation of c-Myc induced apoptosis by p53. Science 265: 2091-2093

53. Pelengaris S, Khan M and Evan GI (2002) Suppression of myc-induced apoptosis in beta cells exposes multiple oncogenic properties of myc and triggers carcinogenic progression. Cell 109: 321-334

54. Kuperwasser C, Hurlbut GD, Kittrell FS, Dickinsn ES, Laurcirica R, Medina D, Naber SP and Jerry DJ (2000) Development of spontaneous mammary tumours in BALB/c p53 heterozygous mice. A model for Li-Fraumeni syndrome. Am. J. Pathol. 157: 2151-2159

55. Rafferty JA, Clarke AR, Sellapan D, Koref MS, Frayling IM and Margison GP (1996) Induction of murine $0^{6}$-alkylguanine-DNA-alkyltransferase in response to ionising radiation is p53 gene dose dependent. Oncogene 12: 693-697

56. Venkatachalam S, Shi YP, Jones SN, Vogel H, Bradley A, Pinkel D and Donehower LA (1998) Retention of wild-type p53 in tumours from p53 heterozygous mice: reduction of $p 53$ dosage can promote cancer formation. EMBO J. 17: 4657-4667

57. Toft NJ, Curtis LJ, Sansom OJ, Leitch AL, Te Riele H, Wyllie AH, Arends MJ, and Clarke AR (2002) Heterozygosity for p53 promotes microsatellite instability on an Msh2 deficient background. Oncogene 21: 6299-6306

58. Jerry DJ, Kittrell FS, Kuperwasser C, Laucirica R, Dickinson ES, Bonilla PJ, Butel JS and Medina D (2000) A mammary-specific model demonstrates the role of the p53 tumour suppressor gene in tumour development. Oncogene 19: 1052-1058

59. Marino S, Vooijs M, van Der Gulden H, Jonkers J and Berns A (2000) Induction of medulloblastomas in p53-null mutant mice by somatic inactivation of $\mathrm{Rb}$ in the external granular layer cells of the cerebellum. Genes Dev. 14: 994-1004

60. Jonkers J, Meuwissen R, van der Gulden H, Peterse $H$, van der Valk $M$ and Berns A (2001) Synergistic tumour suppressor activity of BRCA2 and p53 in a conditional mouse model for breast cancer. Nat. Gene. 29: 418-425

61. Tyner SD, Venkatachalam S, Choi J, Jones S, Ghebranious N, Igelmann H, Lu X, Soron G, Cooper B, Brayton C, Park SH, Thompson T, Karsenty G, Bradley $A$ and Donehower LA (2002) P53 mutant mice that display early ageingassociated phenotypes. Nature 415: 45-53

62. Ferbeyre G, de Stanchina E, Lin AW, Querido E, McCurrach ME, Hannon GJ and Lowe SW (2002) Oncogenic ras and p53 co-operate to induce cellular senescence. Mol. Cell Biol. 22: 3497-3508

63. Schmitt CA, Friedman JS, Yang M, Lee S, Baranov E, Hoffman RM and Lowe SW (2002) A senescence program controlled by $p 53$ and p16INK4a contributes to the outcome of cancer therapy. Cell 109: 335-346

64. Liu G, McDonnell TJ, Montes de Oca Luna R, Kapoor M, Mims B, El-Naggar AK and Lozano G (2000) High metastatic potential in mice inheriting a targeted p53 missense mutation. Proc. Natl. Acad. Sci. USA 97: 41744179

65. Jimenez GS, Mister M, Stommel JM, Beeche M, Barcarse EA, Zhang, XQ, O'Gorman S and Wahl GM (2000) A transactivation-deficient mouse model provides insights into Trp53 regulation and function. Nat. Genet. 26: $37-43$

66. DeVries A, Flores ER, Miranda B, Hsieh H-M, van Oostrom CTM, Sage J and Jacks $T$ (2002) Targeted point mutations of p53 lead to dominantnegative inhibition of wild-type p53 function. Proc. Natl. Acad. Sci. 99: 29482953

67. Luo J-L, Yang Q, Tong W-M, Hergenhahn $M$, Wang Z-Q and Hollstein $M$ (2001a) Knock-in mice with a chimeric human/murine p53 gene develop normally and show wild-type p53 responses to DNA damaging agents: a new biomedical research tool. Oncogene 20: 320-328

68. Luo J-L, Tong W-M, Yoon J-H, Hergenhahn M, Koomagi R, Yang Q, Galendo D, Pfeifer GP, Wang Z-Q and Hollstein M (2001b) UV-induced DNA damage and mutations in Hupki (Human p53 knock-in) mice recapitulate p53 hotspot alterations in sun-exposed human skin. Cancer Res. 61: 81588163

69. Hahn WC and Weinberg RA (2002) Modelling the molecular circuitry of cancer. Nat. Rev. Cancer 2: 331-341

70. Vogelstein B, Lane D and Levine AJ (2000) Surfing the p53 network. Nature 408: $307-310$

71. Brachmann RK, Yu K, Eby Y, Pavletich NP and Boeke JD (1998) Genetic selection of intragenic suppressor mutations that reverse the effect of common p53 cancer mutations. EMBO J. 17: 1847-1859

72. Marin MC, Jost CA, Brooks LA, Irwin MS, O'Nions J, Tidy JA, James N, McGregor JM, Harwood CA, Yulug IG, Vovsden KH, Allday MJ, Gusterson B, Ikawa S, Hinds PN, Crook T, Kaelin WG Jr (2000) A common polymorphism acts as an intragenic modifier of mutant p53 behaviour. Nat. Gene. 25: 47-53

73. D'Orazi G, Cecchinelli B, Bruno T, Manni I, Higashimdo Y, Saito S, Gostissa M, Coen S, Marchetli A, Del Sal G, Piaggio G, Fanicolli M, Appella E, Soddo S (2002) Homeodomain-interactive protein kinase-2 phosphorylates p53 at Ser 46 and mediates apoptosis. Nat. Cell Biol. 4: 11-19

74. Hofmann TG, Moller A, Sirma H, Zentgraf H, Taya Y, Droge W, Will H and Schmitz ML (2002) Regulation of p53 activity by its interaction with homeodomain-interacting protein kinase-2. Nat. Cell Biol. 4: 1-10

75. Oda K, Arakawa H, Tanaka T, Matsuda K, Tanikawa C, Mori T, Nishimori H, Tamai K, Tokino T, Nakamura $Y$ and Taya $Y$ (2000) P53AIP1, a potential mediator of p53-dependent apoptosis, and its regulation by Ser46phosphorylated p53. Cell 102: 849-862

76. Bulavin DV, Demidov ON, Saito S, Kauraniemi P, Phillips C et al (2002) Amplification of PPM1D in human tumours abrogates p53 tumour-suppressor activity. Nat. Gene. 31: 210-215

77. Su Al, Cooke MP, Ching KA, Hakak Y, Walker JR, Wiltshire T, Orth AP, Vega RG, Sapinoso LM, Mogrich A, Patapoutian A, Hampton GM, Schultz PG and Hogenesch JB (2002) Large scale analysis of the human and mouse transcriptomes. Proc. Natl. Acad. Sci. 99: 4465-4470

78. Gillet R, Grimber G, Bennoun M, Caron de Fromentel C, Briand P and Joulin V (2000) The consequence of p53 overexpression for liver tumour development and the response of transformed murine hepatocytes to genotoxic agents. Oncogene 19: 3498-3507 